\title{
PENGARUH PEMAHAMAN KONSEP TERHADAP KEMAMPUAN PEMECAHAN MASALAH MATEMATIKA
}

\author{
Ihwan Zulkarnain ${ }^{1}$, Hadi Budiman ${ }^{2}$ \\ Pendidikan Matematika, FMIPA Universitas Indraprasta PGRI Jakarta \\ Irvan_arie@yahoo.com ${ }^{1}$, Hadibudiman@gmail.com²
}

\begin{abstract}
Abstrak
Tujuan dari penelitian ini adalah untuk menganalisis dan mendiskripsikan pengaruh pemahaman konsep terhadap kemampuan pemecahan masalah matematika. siswa kelas X jurusan Usaha Perjalanan Wisata di Sekolah Menengah Kejuruan Negeri 14 Bekasi. Metode penelitian yang digunakan adalah survei dengan metode analisis korelasi dan regresi sederhana. Sampel yang digunakan dalam penelitian ini sebanyak 30 siswa yang dipilih dengan simple random sampling. Instrumen untuk mengumpulkan data berupa soal esai sebanyak 10 soal yang terdiri dari 5 soal untuk pemahaman konsep serta 5 soal tentang kemampuan pemecahan masalah. Hasil penelitian didapatkan nilai $\mathrm{F}_{\text {hitung }}>\mathrm{F}_{\text {tabel }}(110,02>4,20)$, maka hipotesis $\mathrm{H}_{0}$ diterima dan dapat disimpulkan terdapat pengaruh yang signifikan antara pemahaman konsep (variabel $\mathrm{X}$ ) terhadap kemampuan pemecahan masalah matematika siswa (variabel Y). Penelitian ini telah menemukan dan membuktikan bahwa pemahaman konsep memberikan pengaruh positif yang signifikan terhadap kemampuan pemecahan masalah khususnya dalam pembelajaran matematika.
\end{abstract}

Kata kunci: pemahaman konsep; pemecahan masalah matematika

\section{PENDAHULUAN}

Pendidikan termasuk salah satu aspek kehidupan yang memegang peranan penting di dalam kehidupan bermasyarakat. Suatu negara dikatakan maju, jika kualitas pendidikan negara tersebut baik. Sebaliknya, suatu negara dikatakan tidak maju dalam teknologinya, jika kualitas pendidikan di negara tersebut tidak baik. Menurut Hariyanti (Ubaidah, 2016:4) mengatakan pendidikan suatu hal yang sangat bermanfaat bagi setiap manusia. Dengan adanya pendidikan manusia memperoleh pribadi yang berkualitas yang dapat meningkatkan harkat dan martabat pada dirinya. Dengan dibekali pendidikan, kita mampu membuat keputusan yang tepat dalam mengambil tindakan. Hal ini dikarenakan dalam pendidikan, kita belajar bagaimana cara menjadi orang yang mempunyai tujuan yang jelas, terarah, berpikir kreatif, inovatif, dan mendapatkan pekerjaan yang baik guna memperoleh kehidupan yang layak nantinya. Oleh karena itu, pendidikan adalah hal yang sangat dibutuhkan manusia untuk memperbaiki diri menjadi lebih baik sehingga dapat bersaing seiring perkembangan teknologi dan kebudayaan. 
Research and Development Journal Of Education

Vol. 6 No. 1 Oktober 2019

p-ISSN 2406-9744

e-ISSN 2657-1056

Perkembangan ilmu pengetahuan dan teknologi yang maju dengan sangat cepat mengakibatkan arus informasi datang dari berbagai penjuru dunia secara cepat sehingga untuk tampil unggul pada keadaan yang mudah berubah dan kompetitif tersebut, diperlukan kemampuan memperoleh, memilih, dan mengelola informasi, kemampuan untuk dapat berpikir secara kritis, sistematis, logis, kreatif, dan kemampuan untuk dapat bekerja secara efektif. Sikap dan cara berpikir seperti ini dapat dikembangkan melalui proses pembelajaran matematika karena matematika memiliki struktur dan keterkaitan yang kuat dan jelas antar konsepnya sehingga memungkinkan siapapun yang mempelajarinya dapat berpikir secara rasional. Berdasarkan uraian tersebut jelaslah bahwa matematika harus dipelajari siswa pada setiap jenjang pendidikan, mulai dari sekolah dasar, perguruan tinggi sampai pengaplikasiannya di dalam masyarakat.

Matematika merupakan ilmu bernalar yang penuh dengan konsep dan prinsip, dimana dalam menyelesaikan materi matematika diperlukan suatu kemampuan untuk memahami permasalahan tersebut kemudian mengkonstruksikan dalam bentuk ide-ide matematika dan menyelesaikan ide tersebut sesuai dengan konsep dan prinsip matematika. Namun masih banyak siswa yang belum menguasai kemampuan pemecahan masalah matematika yang ada. Akibatnya, dalam menyelesaikan soal matematika, siswa kurang mampu dalam memecahkan masalah dikarenakan pemahaman materi yang masih rendah.

Kemampuan seseorang dalam mengidentifikasi masalah apalagi memecahkannya itu berbeda-beda. Kemampuan ini banyak sekali ditunjang oleh latar belakang akademis. Pemecahan masalah menurut Hudojo (Giovani, 2013:24) secara sederhana diungkapkan sebagai proses penerimaan masalah sebagai tantangan untuk menyelesaikan masalah tersebut. Sedangkan menurut pendapat Goldstein dan Levin (Rosdiana \& Misu, 2013:2) pemecahan masalah telah didefinisikan sebagai proses kognitif tingkat tinggi yang memerlukan modulasi dan kontrol lebih dari keterampilan rutin dalam rangka memenuhi tuntutan situasi yang tak lumrah.

Sedangkan kemampuan pemecahan masalah matematika adalah kemampuan mencari cara dan metode untuk menyelesaikan masalah dalam matematika melalui kegiatan mengamati, memahami, mencoba, menduga dan menemukan serta meninjau kembali, Suherman (Mahuda 2017:2). Sebab itu siswa 
Research and Development Journal Of Education

Vol. 6 No. 1 Oktober 2019

p-ISSN 2406-9744

e-ISSN 2657-1056

dituntut mampu merepresentasikan permasalahan yang ada ke dalam bentuk ideide matematika yang tepat, agar tercapainya keberhasilan memperoleh jawaban yang sesuai. Ide-ide tersebut bisa didapatkan jika siswa memperoleh pemahaman yang jelas dari konsep yang diajarkan di dalam kelas.

Pemahaman konsep adalah kompetensi yang ditunjukkan peserta didik dalam melakukan prosedur (algoritma) secara luwes, akurat, efisien, dan tepat (Depdiknas, 2006:54). Di samping itu peserta didik terbantu dalam mengembangkan penalarannya. Dalam kurikulum 2006 salah satu tujuan dari pembelajaran matematika adalah pemahaman konsep yang berupa mampu menjelaskan keterkaitan antar konsep dan mengaplikasikan konsep atau algoritma secara luwes, akurat, dan tepat dalam pemecahan masalah.

Sanjaya (Ulia, 2016:20) mengatakan apa yang dimaksud dengan pemahaman konsep adalah kemampuan siswa yang berupa penguasaan sejumlah materi pelajaran, dimana siswa tidak sekedar mengetahui atau mengingat sejumlah konsep yang dipelajari, tetapi mampu mengungkapan kembali dalam bentuk lain yang mudah dimengerti, memberikan interprestasi data dan mampu mengaplikasikan konsep yang sesuai dengan struktur kognitif yang dimilikinya.

Kemampuan pemahaman konsep menurut Asikin (Hartati, 2017:2) adalah suatu kemampuan mengerti, mengubah informasi ke dalam bentuk yang bermakna. Kemampuan pemahaman konsep merupakan kemampuan untuk memahami ide matematika yang menyeluruh dan fungsional. Kemampuan pemahaman konsep akan mempengaruhi kemampuan pemecahan masalah. Dengan mempunyai pemahaman yang baik terhadap konsep-konsep yang ada di dalam matematika, peserta didik diharapkan dapat memiliki kemampuan pemecahan yang baik pula, sehingga peserta didik dapat menyelesaikan permasalahan-permasalahan pada matematika dan dapat mengaplikasikan kemampuannya untuk menyelesaikan permasalahan dalam kehidupan sehari-hari.

\section{METODE}

Penelitian ini merupakan penelitian kolerasional untuk mengetahui apakah pemahaman konsep berpengaruh secara langsung atau tidak terhadap kemampuan pemecahan masalah matematika. Hal ini dilakukan dengan menggunakan pendekatan korelasional, dimana metode penelitian ini yang akan dilakukan 
Research and Development Journal Of Education

Vol. 6 No. 1 Oktober 2019

p-ISSN 2406-9744

e-ISSN 2657-1056

merupakan metode regresi linier sederhana dengan satu variabel bebas dan satu variabel terikat. Instrumen yang diguakan oleh penulis pada penelitian kali ini berupa soal matematika berbentuk essay sebanyak 10 soal yang telah divalidasi tanpa melakukan perlakuan telebih dahulu terhadap subjek penelitian. Uji coba insteumen dilakukan di luar sampel. Data dianalisis terlebih dahulu dengan uji persyaratan, yaitu uji normalitas dan uji liniearitas. Berdasarkan kriteriadalam uji persyaratan analisis data, dilakukan analisis korelasional dan regresi sederhana untuk pengujian hipotesis. Populasi pada penelitian ini adalah seluruh siswa reguler kelas X jurusan usaha perjalanan wisata yang berjumlah 119 siswa dan terdaftar mengikuti mata pelajaran Matematika pada semester genap 2017/2018 di SMK Negeri 14 Kota Bekasi. Sedangkan sampel sebanyak 30. Dasar pengambilan sampel ini juga memperhatikan ciri-ciri antara lain: (1) peserta didik mendapatkan materi berdasarkan kurikulum yang sama, (2) peserta didik diampu oleh guru yang sama, dan (3) peserta didik berada pada tingkat kelas yang sama dan tidak ada kelas unggulan.

Teknik pengambilan sampel dalam penelitian didasarkan pada teknik multi stage random sampling. Untuk memperoleh data tersebut di atas diperlukan teknik atau metode pengumpulan data agar data yang diperoleh relevan atau ada hubungannya dengan masalah penelitian. Adapun metode atau teknik pengumpulan data diantaranya adalah angket, wawancara atau interview, pengamatan atau observasi, ujian atau tes dan dokumentasi. Berdasarkan teori tersebut, maka teknik atau metode pengumpulan data pada penelitian ini adalah menggunakan teknik tes. Sedangkan instrumen yang dipergunakan dalam penelitian ini adalah menggunakan skala interval untuk memperoleh data mengenai pemahaman konsep dan kemampuan pemecahan masalah dengan menggunakan tes berbentuk uraian.

\section{HASIL DAN PEMBAHASAN}

Pada penelitian ini populasi berasal dari kelas X Usaha Perjalanan Wisata SMK Negeri 14 Bekasi Tahun Pelajaran 2017/2018 semester genap sebagai sampel sebanyak 30 siswa yang terdiri dari 11 orang siswa lai-laki dan 19 orang siswa perempuan. 
Research and Development Journal Of Education

Vol. 6 No. 1 Oktober 2019

p-ISSN 2406-9744

e-ISSN 2657-1056

Dari sampel sebanyak 30 siswa tersebut diperoleh nilai atau skor Pemahaman Konsep dan Kemampuan Pemecahan Masalah Matematika siswa melalui tes pada materi Sistem Persamaan Linear Dua Variabel (SPLDV). Berikut ini akan disajikan data hasil penelitian berupa hasil perhitungan akhir. Data pada penelitian ini adalah data yang terkumpul dari tes tertulis.

Dari hasil tes tertulis soal matematika pada materi SPLDV yang menggunakan instrumen tes berbentuk uraian sebanyak 10 butir pada sampel yaitu siswa kelas X UPW I SMK Negeri 14 Bekasi Tahun pelajaran 2017/2018 sebanyak 30 siswa, diperoleh data pemahaman konsep dan pemecahan masalah matematika sebagai berikut:

Tabel 1. Distribusi Frekuensi Pemahaman Konsep.

\begin{tabular}{cccccccc}
\hline No & Interval & $\mathbf{X}_{\mathbf{i}}$ & $\mathbf{X}_{\mathbf{i}}^{\mathbf{2}}$ & $\mathbf{F}_{\text {abs }}$ & $\mathbf{F}_{\mathbf{i}} \mathbf{X}_{\mathbf{i}}$ & $\mathbf{F}_{\mathbf{i}} \mathbf{X}_{\mathbf{i}}^{2}$ & $\mathbf{F}_{\text {rel }}(\boldsymbol{\%})$ \\
\hline 1 & $40-49$ & 44,5 & 1980,25 & 2 & 89 & 3960,5 & $6,7 \%$ \\
2 & $50-59$ & 54,5 & 2970,25 & 4 & 218 & 11881 & $13,3 \%$ \\
3 & $60-69$ & 64,5 & 4160,25 & 6 & 387 & 24961,5 & $20 \%$ \\
4 & $70-79$ & 74,5 & 5550,25 & 12 & 894 & 66603 & $40 \%$ \\
5 & $80-89$ & 84,5 & 7140,25 & 3 & 253,5 & 21240,75 & $10 \%$ \\
6 & $90-99$ & 94,5 & 8930,25 & 3 & 283.5 & 26790,75 & $10 \%$ \\
& Jumlah & 417 & 30731,5 & 30 & 2125 & 155437,5 & $100 \%$ \\
\hline
\end{tabular}

Tabel 2. Distribusi Frekuensi Pemecahan masalah.

\begin{tabular}{cccccccc}
\hline No. & Interval & $\mathbf{X}_{\mathbf{i}}$ & $\mathbf{X}_{\mathbf{i}}^{2}$ & $\mathbf{F}_{\mathbf{a b s}}$ & $\mathbf{F}_{\mathbf{i}} \mathbf{X}_{\mathbf{i}}$ & $\mathbf{F}_{\mathbf{i}} \mathbf{X}_{\mathbf{i}}^{2}$ & $\mathbf{F}_{\text {rel }}(\boldsymbol{\%})$ \\
\hline 1 & $40-48$ & 44 & 1936 & 4 & 176 & 7744 & $13,3 \%$ \\
2 & $49-57$ & 53 & 2809 & 1 & 53 & 2809 & $3,3 \%$ \\
3 & $58-66$ & 62 & 3844 & 8 & 496 & 30752 & $26,7 \%$ \\
4 & $67-75$ & 71 & 5041 & 5 & 355 & 25205 & $16,7 \%$ \\
5 & $76-84$ & 80 & 6400 & 5 & 400 & 32000 & $16,7 \%$ \\
6 & $85-93$ & 89 & 7921 & 7 & 623 & 55447 & $23,3 \%$ \\
& Jumlah & 399 & 27951 & 30 & 2013 & 153957 & $100 \%$ \\
\hline
\end{tabular}

Dari hasil pengukuran variabel pemahaman konsep dan kemampuan pemecahan masalah terhadap 30 peserta didik yang dijadikan sampel melalui soal 
Research and Development Journal Of Education

Vol. 6 No. 1 Oktober 2019

p-ISSN 2406-9744

e-ISSN 2657-1056

bentuk uraian yang dilakukan pada saat penelitian berlangsung. Secara deskriptif, hasil penelitian dapat terangkum melalui tabel berikut ini:

Tabel 3. Rangkuman Data Deskriptif

\begin{tabular}{ccc}
\hline Statistik & Pemahaman Konsep & $\begin{array}{c}\text { Kemampuan Pemecahan Masalah } \\
\text { Matematika }\end{array}$ \\
\hline Nilai Terendah & 98 & 92 \\
Nilai Tertinggi & 40 & 40 \\
Mean & 70,8 & 67,1 \\
Median & 72 & 71,9 \\
Modus & 73,5 & 63,8 \\
Varians & 169,5 & 651,1 \\
Simpangan Baku & 13,02 & 25,5 \\
\hline
\end{tabular}

Uji normalitas diberikan kepada kedua variabel penelitian dan diharapkan data yang diperoleh dari hasil penelitian berdistribusi normal. Untuk menguji kenormalan hasil penelitian digunakan uji normalitas Chi-Kuadrat pada taraf $\alpha=$ 5\% atau sama dengan 0,05 dan disajikan dalam bentuk tabel berikut ini.

Tabel 4. Perhitungan Uji Normalitas Pemahaman Konsep.

\begin{tabular}{ccccccccc}
\hline Interval & $\boldsymbol{f}_{\boldsymbol{o}}$ & $\begin{array}{c}\text { Tepi kelas } \\
\left(\boldsymbol{x}_{\boldsymbol{i}}\right)\end{array}$ & $\boldsymbol{z}_{\boldsymbol{i}}$ & $\boldsymbol{Z}_{\text {tzbel }}$ & $\boldsymbol{F}\left(\boldsymbol{z}_{\boldsymbol{i}}\right)$ & $\mathbf{L i}$ & $\boldsymbol{f}_{\boldsymbol{e}}$ & $\frac{\left(\boldsymbol{f}_{\boldsymbol{o}}-\boldsymbol{f}_{\boldsymbol{e}}\right)^{2}}{\boldsymbol{f}_{\boldsymbol{e}}}$ \\
\hline $40-49$ & 2 & 39,5 & $-2,40$ & 0,4918 & 0,0082 & & & \\
$50-59$ & 4 & 49,5 & $-1,63$ & 0,4484 & 0,0516 & 0,0434 & 1,30 & 0,38 \\
$60-69$ & 6 & 59,5 & $-0,87$ & 0,3078 & 0,1922 & 0,1406 & 4,22 & 0,01 \\
$70-79$ & 12 & 69,5 & $-0,09$ & 0,0359 & 0,4651 & 0,2759 & 8,28 & 0,63 \\
$80-89$ & 3 & 79,5 & 0,67 & 0,2486 & 0,7486 & 0,2951 & 8,85 & 0,35 \\
$90-99$ & 3 & 89,5 & 1,44 & 0,4251 & 0,9251 & 0,1765 & 5,29 & 0,99 \\
$\Sigma$ & 30 & 99,5 & 2,20 & 0,4861 & 0,9861 & 0,061 & 1,83 & 0,75 \\
\hline
\end{tabular}

Dari hasil perhitungan dalam tabel tersebut, didapat nilai $x_{\text {hitung }}^{2}=3.11$ sedangkan dari tabel Chi-Kuadrat untuk $\alpha=0.05 \mathrm{dan} \mathrm{dk}=6-1=5$ didapat nilai $x_{\text {tabel }}^{2}=11,070$. Karena nilai $x_{\text {hitung }}^{2}<x_{\text {tabel }}^{2}$, maka $\mathrm{H}_{0}$ diterima dan disimpulkan bahwa data berdistribusi normal. Maka, data pemahaman konsep siswa berdistribusi normal. 
Research and Development Journal Of Education

Vol. 6 No. 1 Oktober 2019

Tabel 5. Perhitungan Uji Normalitas Kemampuan Pemecahan Masalah.

\begin{tabular}{|c|c|c|c|c|c|c|c|c|}
\hline Interval & $f_{o}$ & $\begin{array}{c}\text { Tepi kelas } \\
\left(x_{i}\right)\end{array}$ & $z_{i}$ & $Z_{t z b e l}$ & $F\left(z_{i}\right)$ & $\mathbf{L i}$ & $f_{e}$ & $\frac{\left(f_{o}-f_{e}\right)^{2}}{f_{e}}$ \\
\hline & & 39,5 & $-1,08$ & 0,3599 & 0,1401 & & & \\
\hline $40-48$ & 4 & & & & & 0,0926 & 2,78 & 0,53 \\
\hline $49-57$ & 1 & 48,5 & $-0,73$ & 0,2673 & 0,2327 & 0,1193 & 3,58 & 0,16 \\
\hline $58-66$ & 8 & 57,5 & $-0,38$ & 0,1480 & 0,352 & 0,14 & 4,2 & 3,44 \\
\hline $67-75$ & 5 & $\begin{array}{l}66,5 \\
75,5\end{array}$ & $\begin{array}{r}-0,02 \\
0,33\end{array}$ & $\begin{array}{l}0,0080 \\
0,1293\end{array}$ & $\begin{array}{c}0,492 \\
0,6293\end{array}$ & 0,1373 & 4,12 & 0,19 \\
\hline $76-84$ & 5 & 84,5 & 0,68 & 0,2517 & 0,7517 & 0,1224 & 3,67 & 0,48 \\
\hline $85-93$ & 7 & 93,5 & 1,03 & 0,3485 & 0,8485 & 0,0968 & 2,90 & $\begin{array}{c}5,79 \\
10,59\end{array}$ \\
\hline
\end{tabular}

Dari hasil perhitungan dalam tabel tersebut, didapat nilai $x_{\text {hitung }}^{2}=10.59$ sedangkan dari tabel Chi-Kuadrat untuk $\alpha=0.05 \mathrm{dan} \mathrm{dk}=6-1=5$ didapat nilai $x_{\text {tabel }}^{2}=11,070$. Karena nilai $x_{\text {hitung }}^{2}<x_{\text {tabel }}^{2}$, maka $\mathrm{H}_{0}$ diterima dan disimpulkan bahwa data berdistribusi normal. Maka, data pemahaman konsep siswa berdistribusi normal.

Tabel 6. Penolong ANOVA Kelinearan Regresi

\begin{tabular}{cccccc}
\hline Sumber Varians & Dk & JK & RJK & $F_{\text {hitung }}$ & F $_{\text {tabel }}$ \\
\hline Total & 30 & 150318 & - & & \\
Regresi (a) & 1 & 142830 & 142830 & & \\
Regresi (b/a) & 1 & 5968,71 & 5968,71 & & \\
Residu & 28 & 1519,29 & 54,26 & 0,39 & 2,43 \\
Tuna Cocok & 9 & 241,52 & 26,83 & & \\
Kesalahan (error) & 19 & 1277,77 & 67,25 & & \\
\hline
\end{tabular}

$\mathrm{F}_{\text {tabel }}$ ditetapkan untuk $a=0,05$ dengan pembilang $(\mathrm{k}-2=9)$ penyebut ( $\mathrm{n}-$ $\mathrm{k}=19$ ), maka didapat $\mathrm{F}_{\text {tabel }}=2,43$. Karena $F_{\text {hitung }}=0,39<F_{\text {tabel }}=2,43$ maka $\mathrm{H}_{0}$ diterima dan dapat disimpulkan data regresi berpola linear.

Berdasarkan data hasil penelitian dan analisis data yang dilakukan di kelas X UPW I SMK N 14 Bekasi, diperoleh data hasil penelitian pemahama konsep yang menunjukan nilai rata-rata sebesar 70,8 nilai median sebesar 72 nilai modus 73,5 dan simpangan baku 13,02. Hasil penelitian kemampuan pemecahan masalah matematika, rata-rata sebesar 67,8 , nilai median sebesar 71,9, nilai modus 63,8 dengan simpangan baku sebesar 25,5. Selanjutnya tentang besarnya pengaruh pemahan konsep terhadap kemampuan pemecahan masalah matematika dapat 
Research and Development Journal Of Education

Vol. 6 No. 1 Oktober 2019

p-ISSN 2406-9744

e-ISSN 2657-1056

dilihat dari besarnya koefisien determinasi sebesar 79,21\% yang berarti bahwa ada pengaruh pemahaman konsep terhadap kemampuan pemecahan masalah matematika yaitu sebesar 79,21\%. Setelah dilakukan uji signifikansi yang menggunakan uji $\mathrm{t}$ didapat $(10,46>1,701)$, sehingga penagaruh tersebut signifikan atau berarti,

Pemahaman konsep yang baik akan meningkatkan kemampuan pemecahan masalah matematika siswa, hal ini sependapat dengan Asikin (Hartati, 2010:12) mengemukakan kemampuan pemahaman konsep merupakan kemampuan untuk memahami ide-ide matematika yang menyeluruh dan fungsional, kemampuan pemahaman konsep akan mempengaruhi kemampuan pemecahan masalah.

Memecahkan sebuah masalah perlu memahami konsep masalah dan startegi yang terorganisir. Dalam proses pemecahan masalah tidak serta-merta langsung selesai, tetapi butuh proses dan langkah-langkah maupun solusi untuk pemecahan masalah tersebut. Menurut Eviliyanida (2010:15) berpendapat solusi pemecahan masalah terdiri dari tiga langkah penelesaian, yaitu memahami masalah, menyelesaikan dan melakukan pengecekan kembali terhadap semua langkah yang telah dikerjakan. Dengan demikian, pemecahan masalah dapat teratasi dengan tepat dan akurat.

Peserta didik sudah seharusnya memiliki kemampuan pemecahan masalah, dikarenakan di dalam kehidupan sehari-hari dan dalam kegiatan pembelajaran akan ditemukan banyak permasalah yang butuh kemampuan untuk memecahkannya. Hal ini sependapat dengan Rusffendi (2012:3) mengatakan pemecahan masalah harus dimiliki peserta didik untuk melatih agar terbiasa menghadapi berbagai permasalahan, baik masalah dalam matematika, masalah dalam bidang studi lain ataupun masalah dalam kehidupan sehari-hari.

Penelitian ini telah menemukan dan membuktikan bahwa pemahaman konsep memberikan pengaruh positif yang signifikan terhadap kemampuan pemecahan masalah khususnya dalam pembelajaran matematika. Di masa yang akan datang diharapkan ada beberapa penelitian yang bertujuan untuk meningkatkan dan mengembangkan peran pemahaman konsep, sehingga terciptanya kemampuan pemecahan masalah yang tepat dan akurat. 
Research and Development Journal Of Education

Vol. 6 No. 1 Oktober 2019

p-ISSN 2406-9744

e-ISSN 2657-1056

\section{SIMPULAN}

Dari hasil dan pembahasan dapat disimpulkan terdapat pengaruh yang positif pemahaman Konsep (X) terhadap kemampuan pemecahan masalah matematika siswa (Y), yang dapat diartikan semakin tinggi kemampuan pemahaman konsep, semakin tinggi pula kemampuan pemecahan masalah matematika. Apabila semakin rendah kemampuan pemahaman konsep, semakin rendah pula kemampuan pemecahan masalah matmatika. Kemampuan siswa untuk memahami konsep (pemahaman konsep) atas materi pembelajaran matematika yang sedang mereka pelajari mempunyai pengaruh yang signifikan terhadap kemampuan siswa untuk memecahkan masalah-masalah yang berkaitan dengan pembelajaran matematika.

Dengan demikian, peneliti menyarankan kepada semua elemen masyarakat yang berada di sekolah terutama guru, bahwa dalam proses pembelajaran matematika hendaknya tidak hanya menekankan peserta didik untuk menghafal rumus matematika, tetapi lebih mengutamakan pesera didik untuk memahami serta memaknai konsep dan rumus matematika juga dengan lebih banyak latihan soal. Proses pembelajaran seperti ini yang dapat meningkatkan kemampuan pemecahan masalah matematika siswa.

\section{DAFTAR PUSTAKA}

Depdiknas. (2006). Standar Kompetensi Mata Pelajaran Matematika Sekolah Menengah Pertama dan Madrasah Tsanawiyah. Jakarta: Puskur.

Eviliyanida. (2010). Pemechan Masalah Matematika. Jurnal Pendidikan Matematika. Vol. 1 No 2. http://ejornal.stikpgetsempema.ac.id

Giovani, N. (2013). Kemampuan Memecahkan Masalah Dalam Kompetensi Dasar Menghitung Keliling dan Luas Segitiga,Segiempat Siswa Kelas VIII SMP Negeri 4 Purworejo Tahun Pelajaran 2012/2013. Ekuivalen. http://ejournal.umpwr.ac.id/index.php/ekuivalen/article/viewFile/407/429

Hartati, Sri. (2017). Pengaruh Kemampuan Pemahaman Konsep, Kemampuan Komunikasi dan Koneksi terhadap Kemampuan Pemecahan Masalah. Jurnal pendidikan matematika, volume 2, nomor 1. http://journal.umsurabaya.ac.id/index.php/matematika/issue/view/90

Hudoyo, Herman. (2012). Pengembangan Kurikulum dan Pembelajaran Matematika. Malang: UM Press.

Mahuda, Isnaini. (2017). Pembelajaran Kooperatif co-op co-op dengan Pendekatan open-ended untuk Menigkatkan Kemampuan Pemecahan Masalah Matematis Siswa SMA. JPPM vol. 10 no. 2. http://jurnal.untirta.ac.id/index.php/JPPM/issue/view/260 
Research and Development Journal Of Education

Vol. 6 No. 1 Oktober 2019

p-ISSN 2406-9744

e-ISSN 2657-1056

Ubaidah, Nila. (2016). Pemanfaatan CD Pembelajaran untuk Meningkatkan Kemampuan Komunikasi Matematis Siswa melalui Pembelajaran Make a Match Jurnal Pendidikan Matematika FKIP Unissula Volume 4 (1). www.research.unissula.ac.id

Ulia, Nuhyal. (2016). Peningkatan Pemahaman Konsep Matematika Materi Bangun Datar Dengan Pembelajaran Kooperatif Tipe Group Investigation Dengan Pendekatan Saintifik Di Sd. Jurnal Penelitian dan Evaluasi Pendidikan. Volume 20, Nomor 2. www.tunasbangsa.stikpgetsempena.ac.id

Rosdiana dan La Misu. (2013). Pengembangan Teori Pembelajaran Perilaku dalam Kaitannya dengan Kemampuan Pemecahan Masalah Matematik Siswa di SMA. Seminar Nasional Matematika dan Pendidikan Matematika FMIPA UNY. Yogyakarta.

Ruseffendi. (2012). Pengajaran Matematika Modern dan Masa kini. Bandung: Tarsito.

Supardi U. S. (2012). Aplikasi Statistika dalam Penelitian. Jakarta: Ufuk Press. 